\title{
Okul Müdürleri Tarafından Yapılan Öğretmen Denetimlerine İlişkin İlkokul Müdürlerinin Görüsşleri
}

\author{
Primary School Principals' Views on School Principals' Activities for the \\ Supervision of Teachers
}

\section{Mehmet Hilmi KOÇ ${ }^{* *}$}

\begin{abstract}
Öz
$\mathrm{Bu}$ araştırmada, okul müdürleri tarafından yapılan öğretmen denetimlerine ilişkin ilkokul müdürlerinin görüşlerinin neler olduğu ortaya konulması amaçlanmıştır. Çalışmada nitel araştırma desenlerinden fenomenoloji deseni kullanılmıştır. Örneklem türü olarak amaçlı örnekleme yöntemi seçilmiştir ve maksimum çeşitlilik stratejisi kullanılmıştır. Çalışma grubu 20 ilkokul müdüründen oluşmaktadır. Veri toplama aracı olarak görüşme yönteminden yararlanılmıştır. Verilerin analizinde içerik analizi kullanılmıştır. Okul müdürlerinin öğretmen denetimi konusunda yetkinlik düzeylerinin düşük olduğu, bu konuda hizmetiçi eğitime ihtiyaçlarının bulunduğu ve yapılan denetimlerin yeterince işlevsel olmadığı tespit edilmiştir. Ders denetimlerine yeterince vakit ayrılamadığı ve öğretmen denetimlerinin müfettişlerden alınıp tamamen okul müdürlerine verilmesinin beraberinde bir denetim boşluğunun oluşmasına yol açtığı sonucuna ulaşılmıştır. Müdürlere öğretmen denetimlerini daha işlevsel yapabilmeleri ve yetkinliklerini artırılabilmeleri için uygulama ağırlıklı hizmetiçi eğitimler verilmesi önerilebilir.
\end{abstract}

Anahtar Kelimeler: Denetim, Ders Denetimi, Okul Müdürlerinin Görüşleri

\begin{abstract}
This study aims to reveal the primary school principals' views on the school principals' activities conducted for the supervision of teachers. Phenomenological design which is one of the qualitative research designs has been used in this study. Purposive sampling method was preferred as a type of sampling, and maximum variation strategy was used. The study group consisted of 20 primary

* Bu çalışma "9. Uluslararası Eğitim Denetimi” Kongresinde (01-03 Kasım 2017, Antalya) sözlü bildiri olarak

* Dr., İç Denetçi, İstanbul Büyükşehir Belediyesi, kocmehmethilmi@gmail.com
\end{abstract} sunulmuştur. 
school principals. Interview method was utilized as a data collection tool. Furthermore, content analysis method was used in the data analysis. It has been found that the level of competence of the school principals on the supervision of teachers was low, they need for in-service training activities, and the supervision procedures carried out were not functional enough. It has been concluded that a supervision gap has occurred as enough time has not be spared for supervision of the courses and as the power to supervise the teachers has been taken from the supervisory investigators and given to the school principals. Therefore, the principals can be provided with a practice-oriented training so that they can proceed the supervision activities in a more functional way and increse their competence in the relevant field..

Keywords: Supervision, Course Supervision, School Principals' Views

\section{Giriş}

Denetim, planlanan örgütsel amaçlardan sapmayı önlemek için örgütün işleyişini izleme ve düzeltme (Başaran, 2000) ya da kamu yararı adına davranışı kontrol etme (Bursalığlu, 1991) sürecidir. Eğitim örgütleri açısından bakıldığında denetim; öğrenme-öğretme sürecinin geliştirilmesi için öğretmene yapılan yardım (Wiles, 1967); öğretimin iyileştirilmesi ve öğrenci başarısının arttırılması amacıyla öğretmenin, öğretimine odaklanma (Sullivan ve Glanz, 2005); okulların amaçlarından sapmasını önlemek için işleyişini izleme ve düzeltme (Lunenburg \& Ornstein, 2013) ve genel olarak eğitim programının bütününün değerlendirilmesidir (Cogan, 1973). Özden (1992) denetimi "sürekli bir eğitim” olarak tanımlanmıştır. Harris (1998) denetimi daha çok öğretmenin değerlendirilmesi olarak ele almış ve bu anlamda denetimin önemini beşe ayırmıştır: öğretim ve öğrenmeyi sağlamak, öğretmenlere destek, yardım ve geribildirim vermek, okuldaki öğrenmeyi sürdürmede ve teşvik etmede öğretmenin katalizör görevi gördüğünün anlaşılmasını sağlamak, eğitimi olumsuz etkileyen dış gerekçelere karşı koyabilmek ve yeni geliştirilmiş öncü uygulamaları teşvik etmek.

Eğitim sisteminde denetim ihtiyacı ülkelerin resmi okullar açmaya başlaması ile birlikte ortaya çıkmıştır. İlk başlarda denetim kontrol etme amacıyla yapılmış ve eğitim denetçileri, öğretmeninin yanlış yaptığı her şeyi ortaya çıkarma amacıyla hareket etmişlerdir. Kontrolleri önemseyen klasik denetim modeli 1930’lu yıllarda yerini standartlaşmanın önemsendiği bilimsel denetim modeline bırakmıştır. Bilimsel denetim modeli, öğretmenliğin profesyonelleşmesi, öğretmenlik mesleğinin standartlarının belirlenmesi ve bunlara uygunluğun aranması açısından büyük katkılar getirmiştir. İkinci dünya savaşından sonra demokratik denetim anlayışı ortaya çıkmış ve öğretmenin sadece teknik yönü değil duygusal yönü de önemsenmeye başlamıştır. 1960 ve sonrasındaki yıllarda sınıf yaşantılarını merkeze alan kliniksel denetim modeli, öğretmen-denetçi etkileşimini ve öğretmenin mesleki gelişimini önemsemiştir. Gelişimsel ve farklılaşmış denetim modelleri günümüz denetim yaklaşımları arasında yer almaktadır. Gelişimsel denetim, öğretmenin gerçek gereksinimlerini belirlemeyi ve onun gelişim dönemine uygun değerlendirme yapabilmeyi amaçlamaktadır. Farklılaşmış denetim, alacağı denetim ve değerlendirme hizmetlerinin türleri konusunda öğretmene seçenekler sunan bir modelidir. Denetçilerin gelişimsel ve farklılaşmış denetim yapabilmeleri için iyi eğitim almış olmaları gerekmektedir (Aydın, 2014; Henson, 2007; Sullivan \& Glanz, 2009). 


\section{Öğretmen Denetimi}

Öğretmen denetimini, öğretmenlerin öğretim ve eğitim etkinliklerindeki çalışmalarının gözlenmesi, incelenmesi ve değerlendirmesidir (Taymaz, 2015). Öğretmen denetimleri öğretmenin ders içindeki ve dışındaki etkinliklerinin değerlendirilmesi şeklinde ikiye ayrılır. Öğretmenin etkililiğinin değerlendirilmesi, bazı standart ölçme araçları kullanmak suretiyle, öğretmeni derecelendirme, notlandırma veya sınıflandırma olarak ifade edilebilir (Sergiovanni \& Starratt, 1979). Yapılan denetimler, öğretmenlerin bireysel ihtiyaçlarına cevap vermeli ve onların tutum ve ilişkilerini geliştirebilmelidir (Marks, Stoops \& King-Stoops, 1985). Öğretmenin etkililiğini değerlendirmede kullanılan en iyi yöntem ders denetimleridir. Ders denetimlerinde sınıfın doğal ortamının bozulabileceği, öğretmenin noksan ve yanlışlarını gizleyebileceği ve nesnel veri sağlanamayacağı gibi eleştiriler gelse de öğretmenin sınıf ortamındaki durumunu saptamanın daha iyi bir yöntemi henüz bulunmuş değildir. Ders denetimleri ağırlıklı olarak gözlem yoluyla yapılır. Gözlemin bakmaktan farklı planlı ve sistemli bir eylem olduğu unutulmamalıdır. Okul müdürü derste neleri nasıl gözleyeceğini ve değerlendireceğini önceden planlamalıdır. Gözlenilmesi düşünülen durumların gözlenebilir ve anlamlı olması önemlidir. Ayrıca öğretmenin yalnızca dersteki etkinlikleri değerlendirilerek denetim yapılmış olunmaz. Öğretmenin değerlendirilmesinde ikinci aşama, öğretmenin ders dışı etkinlikleridir. Öğretmenin derse hazırlanması, öğrenci çalışmalarının değerlendirilmesi, nöbet işleri, sosyal kulüp ve rehberlik çalışmaları, devam durumu, genel tutum ve davranışları bu değerlendirme kapsamında ele alınabilecek belli başlı hususlardır. Öğretmen etkililiğini değerlendirmesinde, öğretmenle görüşme, öğrenci ve veli değerlendirmesi ve öğrenci başarısı yoluyla değerlendirme yöntemleri de kullanılan diğer yaklaşımlar arasındadır (Başar, 2000; Haefele, 1981; Taymaz, 2015) .

Öğretmeni mevcut performansı konusunda bilgilendirmek, mesleğe ve çevreye uyumunu sağlamak, gelişimi konusunda uyarmak, yeni beceriler kazanması için teşvik etmek, güçlü ve geliştirmeye açı alanlarını belirlemek öğretmen denetiminin amaçları olarak sayılabilir. Yüksek düzeyde kalitenin ve nesnelliğin sağlanabilmesi için denetimlerde öğretmenleri değerlendirirken standartlar geliştirilmeli ve düzenli olarak kullanılmalıdır. Eğer öğretmen denetimlerinde yapılan değerlendirmelerin inandırıcı ve adil olması isteniyorsa mevcut öğretmen değerlendirme sistemindeki var olan eksiklikleri ortaya çıkarılmasına ve düzeltilmesine yardım edecek öğretmen değerlendirme standartlarının desteklenmesi gerekmektedir. Bütün aşamalarda öğretmen değerlendirme uygulamaları kabul edilebilir ve güvenilir olmalıdır. Profesyonel olarak geliştirilmiş standartlar bu amaca ulaşılmasına yardım edecektir. Öğretmenin sınıf içerisinde etkinliğini artırmanın en büyük yollarından biri öğretmenin nesnel bir şekilde denetlenmesinden geçmektedir. Denetimlerde nesnelliği engelleyen hususlardan bazıları şunlardır: tek etkene göre değerlendirme yapma; edimi değil kişiyi değerlendirmek; değerlendiricinin yetişme noksanlığ değerlendirmede kullanılacak ölçütlerin yokluğu ya da yetersizliği ve denetçinin bir-iki dersine girerek öğretmen hakkında uzun dönem geçerli olabilecek değerlendirme yapması (Aydın, 2014; Başar, 2000; Shinkfield ve Stufflebeam, 1995; Taymaz, 2015).

ABD tarafından 2009 yılında uygulanmaya başlanan "En İyiye Ulaşma Girişimi” (Race to the Top Initiative) adlı eğitim reformu girişiminde öğretmenlerin performanslarının 
değerlendirilmesinde üzerinde durulan iki önemli husus şu şekildedir: (1) öğretmenin değerlendirilmesinde öğrencinin başarısını bir ölçüt olarak kullanmak, (2) öğretmenin pedagojik başarısını daha titiz şekilde ölçmek. Dolayısıyla öğretmen değerlendirmesi çalışmalarının ölçüm ve geliştirme olmak üzere iki ana amacı bulunmaktadır. Bunların her ikisi de aynı derece önemli olmakla birlikte öğretmen değerlendirilmelerinde daha çok ölçüm yönünün ağır bastığı söylenebilir. Oysa ölçümün yanında öğretmenin gelişimi teşvik edilmeli ayrıca var olan gelişim düzeyi tespit edilip gerekli ödüllendirmeler yapılmalıdır (Marzano, 2012; Marzano ve Toth, 2013).

\section{Okul Müdürlerinin Denetim Görevi}

Okulun amaçlarına göre yaşatılmasından birinci derecede sorumlu olan kişi okul müdürüdür. Okul müdürü planlama, örgütleme, eğitim, geliştirme ve kontrol aşamalarından oluşan yönetim süreçlerinde, denetim fonksiyonuna gereken önemi vererek bunu sağlayabilir. Sergiovanni \& Starratt (1979) iyi bir denetim yapabilmenin profesyonel olmayı gerektirdiğini belirtmektedirler. Denetim aynı zamanda okul müdürünün liderlik rollerinden biridir (Knoll, 1987). Okul müdürü öğretimsel liderliğin bir gereği olarak yaptı̆̆ı denetim çalışmaları ile öğretmenin yeterliğini artırabilmeli ve öğretmene ihtiyacı halinde mesleki rehberlik yapabilmelidir (Mohanty, 2005). Okul müdürü denetimler yoluyla öğretmenlerin gelişimine katkı sunmalıdır. İşgören geliştirme, yöneticilere yeni verilmiş bir sorumluluk değildir. $\mathrm{Bu}$ sorumluluk zaten her yöneticiden beklenmektedir (Aydın, 2014).

Türk Eğitim Sisteminde denetim, 1840 'lı yllarda sibyan ve rüşdiye mekteplerinde öğretim aksaklıklarının giderilmesi ve öğretmenlerin mesleki yeteneklerini sağlamak amacıyla teftiş görevi yapan muinlerin (müfettiş) atanması ile başlamıştır. Cumhuriyet döneminde, Milli Eğitim Bakanlığı merkez teşkilatında bakanlık maarif müfettişleri, taşra teşkilatında ise ilköğretim müfettişleri olmak üzere iki tür eğitim denetçisi oluşturulmuştur. MEB'de 2014 yılına kadar kurum ve ders denetimleri ağırlıklı olarak müfettişler tarafından yerine getirilmiştir (Taymaz, 2015). Ancak 2014 yılında yayınlanan "Millî Eğitim Bakanlığı Rehberlik ve Denetim Başkanlığ İle Maarif Müfettişleri Başkanlıkları Yönetmeliği”nde yapılan bir değişiklikle müfettişlerden ders denetim yetkisi alınmıştır. Bu tarihten itibaren kurumların denetimi müfettişler tarafından yürütülmeye devam etmiş ancak, ders denetimleri sadece okul müdürleri tarafından yapılmaya başlanmıştır. Şu anda ülkemizde öğretmen denetim sisteminin merkezinde okul müdürleri bulunmaktadır. (24/5/2014 tarihli ve 29009 sayılı MEB Rehberlik ve Denetim Başkanlığı ile Maarif Müfettişleri Başkanlıkları Yönetmeliği). Dolayısıyla okul müdürlerinin öğretmen denetimlerindeki yetkinlik düzeylerinin ne olduğu ve yaptıkları öğretmen denetimlerin işlevsel olup olmadığı daha da önemli hale geldiği ifade edilebilir.

Alanyazında 2014 yılından itibaren tamamen okul müdürleri tarafından yapılmaya başlanan öğretmen denetimleri hakkında sınırlı sayıda araştırma bulunmaktadır (Ergen ve Eşiyok, 2017; Tonbul ve Baysülen, 2017; Yeşil ve Kış, 2015). Bu araştırmalarda ağırlıklı olarak öğretmen görüşlerine yer verildiği görülmektedir. Öğretmen denetimlerinin işlevsel olup olmadığını, okul müdürlerinin yetkinlik düzeyini ve denetimlerin nasıl yapıldığını okul müdürlerinin görüşlerine göre araştıran çalışmalara ihtiyaç bulunmaktadır. 
$\mathrm{Bu}$ araştırmada, okul müdürleri tarafından yapılan öğretmen denetimlerine ilişkin ilkokul müdürlerinin görüşlerinin neler olduğu ortaya konulması amaçlanmıştır. İlkokul müdürlerinin, öğretmen denetimleri konusundaki yetkinlik düzeylerini nasıl gördükleri, okul müdürlerince yapılan öğretmen denetimlerini işlevsel bulup bulmadıkları, ders denetimlerini nasıl yaptıkları ve müfettişlerin öğretmen ders denetimlerine girmemesinin etkileri hakkında neler düşündükleri ortaya konulmaya çalışılmıştır.

\section{Yöntem}

Araştırma deseni, çalışma grubu, veri toplama aracı ve veri analizine ilişkin bilgiler bu başlık altında sunulmuştur.

\section{Araştırma Deseni}

Katılımcıların okul müdürleri tarafından yapılan öğretmen denetimlerine ilişkin görüşlerini ortaya koymayı amaçlayan bu araştırmada nitel araştırma deseni kullanılmıştır. Nitel araştırmalar, okuyucunun insan deneyimlerine ilişkin kavrayış geliştirmesini ve duyarlılık kazanmasını sağlamayı amaçlanmaktadır (Knafl \& Howard, 1984). Nitel araştırmalar sayesinde insanların bir olguyu nasıl anlamlandırdıkları ve yorumladıkları ortaya çıkabilmektedir (Denzin \& Lincoln, 2005).

Katılımcıların öğretmen denetimlerine ilişkin deneyimlerinin betimlenmesi amaçlandığında bu çalışmada fenomenolojik araştırma yöntemi kullanılmıştır. Fenomenoloji deseni farkında olduğumuz ancak derinlemesine ve ayrıntılı bir anlayışa sahip olmadığımız olaylar, deneyimler, algılar ve durumlar gibi olgulara odaklanmaktadır (Yıldırım ve Şimşek, 2011). Olgubilim bize bir olayın günlük yaşamda nasıl geliştiğini analiz etmemizi ve bu analizler sonucunda olayları değerlendirebilecek temel bakış açıları kazanabilmemizi sağlar (Ashworth \& Lucas, 1998). Başka bir ifadeyle, evrensel gerçekliğin, olayların veya varlıkların doğalarını betimleyebilmek için kişisel deneyimleri fenomenlere indirgemektir (Creswell, 2007). Bu araştırmada fenomenoloji deseni kullanılarak, okul müdürlerinin yaptıkları öğretmen denetimlerine ilişkin algı ve deneyimlerinin nasıl olduğu ilk elden ortaya konulması amaçlanmıştır. Deneyimlerin ve yorumların, adil ve araştırmacının önyargılarından mümkün olduğunca uzak bir şekilde yansıtılmasında etkili olduğu düşünüldügünden fenomenolojik araştırma yöntemi tercih edilmiştir (Tufford \& Newman, 2012). Ayrıca çok sayıda bireyin bir fenomene ilişkin ortak deneyimlerinin neler olduğunun anlaşılması amaçlandığı için bu yöntem tercih edilmiştir. Katılımcıların kişisel deneyimlerin mümkün olduğu kadar parantez içine alınarak araştırma ve yorumlama süreci yürütülmüştür. Çalışma grubu fenomeni deneyimleyen katılımcılardan oluşturulmuş ve onlarla yapılan çoklu görüşmeler yolu ile veriler elde edilmiştir. Verilerin elde edilebilmesi için katılımcıların çalışma konusu fenomene ilişkin deneyimlerini ve algılarını ortaya çıkaracak açık uçlu sorular hazırlanmıştır.

\section{Çalışma Grubu}

Çalışma grubunu 2017-2018 yılları içinde İstanbul'un Çekmeköy ve Ataşehir ilçelerinde görev yapmakta olan 20 ilkokul müdürü oluşturmaktadır. Bu sayede optimum veri büyüklüğüne ulaşılarak 
kategorilerin doygunluğu sağlanmıştır. Veri doygunluğu kategorilerdeki verilerin tekrarlanmalarına yol açmaktadır. Tekrarlamalar ise araştırmanın kapsamlılığı ve tamlığını göstermektedir (Morse, 1991). Araştırmada amaçlı örnekleme türlerinden maksimum çeşitlilik örnekleme stratejisi kullanılmıştır. Bunun için cinsiyet, yöneticilik kıdemi ve okulda görev yapan öğretmen sayısı farklılık arz eden müdürler araştırma grubuna dâhil edilmiştir. Bu sayede nitel araştırmalarda inandırıcilığın ölçütlerinden biri olan veri çeşitlemesi koşulu elde edilmiştir (Arastaman, Öztürk Fidan ve Fidan, 2018). Katılımcllara ilişkin demografik bilgiler Tablo 1'de sunulmuştur:

Tablo I.

Katılımcıların Demografik Özellikleri

\begin{tabular}{ccccc}
\hline Sira No & Rumuz & Cinsiyet & Müdür. Hizmet Yllı & Öğretmen Sayısı \\
\hline 1 & M1 & Erkek & 1 & 16 \\
2 & M2 & Erkek & 35 & 72 \\
3 & M3 & Erkek & 10 & 45 \\
4 & M4 & Kadın & 7 & 68 \\
5 & M5 & Erkek & 7 & 32 \\
6 & M6 & Erkek & 3 & 21 \\
7 & M7 & Erkek & 6 & 52 \\
8 & M8 & Erkek & 11 & 34 \\
9 & M9 & Kadın & 13 & 37 \\
10 & M10 & Erkek & 8 & 64 \\
11 & M11 & Erkek & 4 & 56 \\
12 & M12 & Kadın & 2 & 18 \\
13 & M13 & Kadın & 4 & 44 \\
14 & M14 & Erkek & 16 & 26 \\
15 & M15 & Erkek & 8 & 58 \\
16 & M16 & Kadın & 5 & 31 \\
17 & M17 & Kadın & 21 & 32 \\
18 & M18 & Erkek & 13 & 19 \\
19 & M19 & Erkek & 10 & 24 \\
20 & M20 & Erkek & & 42 \\
\hline
\end{tabular}

Tablo 1'de görüldüğü üzere katılımcıların 15’i erkek ve 6’sı kadındır. Katılımciların 7’si 1-5 yıl, 7'si 6-10 yıl ve 6’sı 11 yıl ve üstü yöneticilik kıdemine sahip olduklarını ifade etmişlerdir. Görev yapılan okulların 6'sında 1-30, 8'inde 31-50 ve 6'sında 51 ve üstü sayıda öğretmen görev yapmaktadır. Araştırmada katılımcıların özel ve kurumsal kimliklerinin gizliliği ilkesine bağlı kalınarak kimliklerini yansıtıcı bilgilere yer verilmemiştir. Bunun yerine her katılımcıya "M1" ile "M20" arasında bir rumuz verilmiştir.

\section{Verilerin Toplanması}

Öğretmen denetimlerine ilişkin önceki çalışmalar taranarak, saha ziyaretleri yapılarak ve çeşitli okul müdürleriyle görüşmeler yapılarak yarı yapılandırılmış görüşme formu 
oluşturulmuştur. Görüşme formunda hazırlanan soruların açık uçlu olmasına özen gösterilmiştir. Katılımcılarında onayı alınarak görüşmelerin tamamı kayıt cihazına kaydedilmiştir. Yeterli verinin toplanmasını sağlamak amacıyla tekrarlı sorgulamalar yapılmıştır. Sorular katılımcılar tarafından anlaşılmadığında farklı şekillerde sorulmuştur (Shenton, 2004). Görüşmeler 1 saat ile 2 saat arasında sürmüştür. Nitel araştırmalarda inandırıcılık ölçütlerinden biri olan katılımcı onayını almak için katılımcılardan görüşme kayıtlarını kontrol etmeleri istenmiştir. Bu sayede katılımcıların deneyim ve yorumlamaları arasında uyum olup olmadığı incelenmiştir. (Guba, 1981). Katılımcılar bazı sorularda birden fazla görüş ifade etmiştir.

\section{Verilerinin Analizi}

Görüşme yoluyla toplanan veriler içerik analizi tekniği kullanılarak analiz edilmiştir. İçerik analizi bir kodlama işlemidir ve ham verileri standart biçimlere dönüştürmek için yapılır (Babbie, 2006). Bu doğrultuda ham veriler metinlere dönüştürülerek kodlamalar oluşturulmuştur. Ardından kodlamalar temalara dönüştürülmüştür. Metin içeriklerinin ortak noktaları ortaya çıkarılarak temalara dağıtılmıştır (Berg, 2001). Katılımcı kontrolü, fenomenin ayrıntılı bir şekilde betimlenmesi ve uzman değerlendirmesi yapılan araştırmanın inandırıcılı̆̆ını artırdığı belirtilmektedir (Arastaman, Öztürk Fidan ve Fidan, 2018). Bu nedenle görüşme dökümleri katılımcılara gönderilerek katılımcıların teyidi sağlanmıștır. Ayrıca verilerin analizinde iki uzmandan geri bildirim alınmıştır.

\section{Bulgular}

Katılımcıların “öğretmen denetimlerini yaparken kendinizi yeterli buluyor musunuz?” sorusuna verdikleri cevaplar "denetimde yetkinlik" teması altında toplanmıştır. Denetimde yetkinlik temasına ilişkin alt temalar ve frekanslar Tablo 2'de sunulmaktadır.

\section{Tablo 2}

Denetimde Yetkinlik Temasına Ilişkin Alt Temalar ve Frekanslar

\begin{tabular}{lll}
\hline Ana tema & Alt temalar & f \\
\hline & Ders denetimi konusunda eğitime ihtiyacım var & 20 \\
& Öğretmenin performansının değerlendirilmesi konusunda eğitime ihtiyacım var & 20 \\
& Öğretmen denetimi konusunda hiç bir eğitim almadık & 18 \\
Denetimde & Yetkin olduğumu düşünmüyorum & 17 \\
Yetkinlik & Müfettişlerden öğrendiklerimi uyguluyorum & 12 \\
& Eğitim yönetimi ve denetimi alanında yüksek lisans yaptım & 4 \\
& Öğretmen denetimi konusunda kendimi yetkin buluyorum & 3 \\
& Hizmetiçi eğitim aldım ama içi boştu & 2 \\
\hline
\end{tabular}

Tablo 2 incelendiğinde denetimde yetkinlik temasına ilişkin verilen yanıtların, "ders denetimi konusunda eğitime ihtiyacım var”, "öğretmenin performansının değerlendirilmesi konusunda eğitime ihtiyacım var”, “öğretmen denetimi konusunda bize bir eğitim verilmedi”, “yetkin 
olduğumu düşünmüyorum", "müfettişlerden öğrendiklerimi uyguluyorum", "eğitim yönetimi ve denetimi alanında yüksek lisans yaptım", "öğretmen denetimi konusunda kendimi yetkin buluyorum" ve "hizmetiçi eğitim aldım ama içi boştu" şeklinde sekiz kategoride toplandığı görülmektedir. Katılımcıların verdikleri yanıtlardan bazıları aşă̆ıda yer almaktadır:

Eğitim yönetimi ve denetimi semineri aldım. Ama içeriği çok boştu. İşolsun mukabilinden bir eğitimdi. İyi düşünülmüş ama iyi planlanmamış bir eğitimdi. Altı saatlik bir eğitimdi. İki saatte bitti. O da çay içme ve sohbet etme ile geçti. (M2)

Öğretmen ders denetimleri ile ilgili özel bir eğitim almadım. Okulumuza gelen müfettişlerin önerileri ve onların daha önce ögrretmen ders denetimi uygulamalarım dikkate alarak öğretmen denetimlerini yapmaya çalışıorum. Daha çok müfettişlerden öğrendiğimi uyguluyorum. (M3)

Öğretmen denetimlerinin nasıl yapılacağı ile ilgili bir eğitim almadım. Almayı isterim. Branşı sınıf öğretmenliği olan bir okul müdürünün sinıf öğretmenlerinin dersini denetlerken zorlanmayacă̆ın ama farklı branşlarda zorlanacağın düşünüyorum. (M14)

Sinı öğretmenliğinde yetkin olduğumuzu söyleyebiliriz. Ama diğer branşlarda yetkinliğimiz olduğunu söyleyemem. Ders denetimi nasıl yapılır diye bir eğitim almadım. Kesinlikle böyle bir eğitime ihtiyaç var. Biz kendi metodumuzu uyguluyoruz. Bu tür eğitimler bu işi profesyonel bir şekilde yapmamızı sağlayacaktır. Öğretmen ders denetimi diye matbu bir defter var. Buradaki maddelere bakarak öğretmen ders denetimlerini yapıyorum. (M17)

Katılımcılara "yeterliliğinizi geliştirmeye ihtiyaç duyuyor musunuz?", "hangi alanlarda eğitim almaya ihtiyaç duyuyorsunuz?" soruları sorulmuştur. Katılımcıların verdikleri cevaplar "eğitim ihtiyacım" teması altında toplanmıştır. Eğitim ihtiyacım temasına ilişkin alt temalar ve frekanslar Tablo 3'de sunulmaktadır.

\section{Tablo 3}

Eğitim Ihtiyacım Temasına Ilişkin Alt Temalar ve Frekanslar

\begin{tabular}{lll}
\hline Ana tema & Alt temalar & f \\
\hline & Öğretimsel liderlik & 20 \\
& Mesleki rehberlik & 17 \\
& İnsani ilişkiler ve iletişim & 12 \\
Eğitim İhtiyacım & Öğretmenin moral ve motivasyonunu yükseltme & 11 \\
& Objektif değerlendirme yapabilme & 11 \\
& Sınıf yönetimi & 8 \\
& Öğgetim yöntem ve teknikleri & 8 \\
\hline
\end{tabular}

Eğitim ihtiyacım teması, "öğretimsel liderlik", "mesleki rehberlik", "insani ilişkiler ve iletişim", "öğretmenin moral ve motivasyonunu yükseltme", "objektif değerlendirme yapabilme", "sınıf yönetimi” ve "öğretim yöntem ve teknikleri” şeklinde yedi kategoride toplandığı görülmektedir. Katılımcıların eğitim ihtiyacım temasına ilişkin söyledikleri ifadelerden bazıları aşağıdadır: 
Yeterliliğimiz denetimle ilgili çok düşük. Çoğu yönlerden eksiğiz. Öğretmene yön verme, liderlik etme ve mesleki açılım sağlamayı yapamıyoruz. Öğretmen mevzuatın istediklerini yerine getirtsin yeter diyoruz. Öğretmene moral vermeyi taltif etmeyi yapamıyorum. İnsani ilişkilerde eğitim almaya ihtiyactm var sanki.(M4)

Okul müdürleri rehberlik yapamıyor. Bu müdür atama kriterlerinden kaynaklanıyor. Mevcut müdürlerin liyakatları ve yetkinlikleri rehberliğe dayalı bir denetimin yapılmasına yetmiyor. (M6)

Özellikle İnsani ilişkiler noktasında müdür arkadaşların eğitime ihtiyaçları olduğunu düşünüyorum. Bazen çok kırıcı olabiliyorlar. Performans değerlendirmede çok hatalar yaptık. Objektif olamadık. Öğretmen arkadaşlar tarafindan verilen puanlara itiraz edildi. Meslektaşları ile mahkemelik olan müdür arkadaşlar oldu. Öğretmen arkadaşlardan bazıları verilen puanları beğenmedi. Müdür arkadaşların verdikleri notlara dair ellerinde bir veri (ölçüt) yoktu.(M16)

Öğretmenin sınıf içerisindeki eğitim öğretimine, ders işleyişine karışmıyorum. Çünkü bunlara bakabilecek yeterlilikte değilim. Ama dersin dişındaki rutin görülebilecek şeyleri denetliyorum. Panolar, nöbet, belirli gün ve haftalara ilişkin hassasiyeti, törenlere katılıyor mu? Bu faaliyetlere öğrenciyi katıyor mu? Denetimde bunlara bakmayı amaçlıyorum. (M18)

Okul müdürlerine "yaptığınız denetimlerin işlevsel olduğunu düşünüyor musunuz?”, “yapılan denetimlerin öğretmene ne gibi katkıları olduğunu düşünüyorsunuz?” soruları sorulmuştur. Okul müdürlerinin verdikleri cevaplar doğrultusunda "denetimde işlevsellik" teması oluşturulmuştur. Denetimde işlevsellik temasına ilişkin alt temalar ve frekanslar Tablo 4'de sunulmaktadır.

\section{Tablo 4}

Denetimde Işlevsellik Temasına Iliş̧kin Alt Temalar ve Frekanslar

\begin{tabular}{lll}
\hline Ana tema & Alt temalar & f \\
\hline & İdari işlerin yoğunluğundan denetime yeterince vakit ayıramıyorum & 20 \\
& Yetersizliği tespit edilen öğretmenler üzerinde yaptırım yetkimiz yok & 18 \\
& Öğretmenin mesleki gelişimine katkı sunamıyorum & 17 \\
& Yaptı̆̆ımız denetimler işlevsel değil & 17 \\
& Öğretmenler yaptığımız denetimleri ciddiye almıyor & 16 \\
Denetimde & Profesyonel bir denetim yaklaşımına sahip değilim & 14 \\
İşlevsellik & Kıdemli öğretmenlere bir katkısı olmuyor & 12 \\
& Denetim sonucunda giderilmesi istenen eksiklikler giderilmiyor & 11 \\
& Değerlendirme notu verirken üst yönetimlerden ve sendikalardan baskı görüyoruz & 10 \\
& Denetim esnasında çok fazla iletişim hatası yapıyorum & 8 \\
& Öğretmenlerle aram açlmasın diye denetim yapmıyorum & 6 \\
& Mesleğe yeni başlayan öğretmenler üzerinde olumlu etkisi daha fazla & 5 \\
& Müfettişlere göre daha işlevsel & 4 \\
\hline
\end{tabular}

Tablo 2 incelendiğinde denetimde işlevsellik temasına ilişkin verilen yanıtların, "idari işlerin yoğunluğundan denetime yeterince vakit ayıramıyoruz”, “yetersizliği tespit edilen öğretmenler üzerinde yaptırım yetkimiz yok”, “öğretmenin mesleki gelişimine katkı sunamıyorum”, 
“yaptığımız denetimler işlevsel değil”, “öğretmenler yaptığımız denetimleri ciddiye almıyor”, "profesyonel bir denetim yaklaşımına sahip değilim”, "kıdemli öğretmenlere bir katkısı olmuyor", "denetim sonucunda giderilmesi istenen eksiklikler giderilmiyor", "değerlendirme notu verirken üst yönetimlerden ve sendikalardan baskı görüyoruz", "denetim esnasında çok fazla iletişim hatası yapıyorum”, “öğretmenlerle aram açılmasın diye denetim yapmıyorum”, "mesleğe yeni başlayan öğretmenler üzerinde olumlu etkisi var", ve "müfettişlere göre daha işlevsel” şeklinde on dört kategoride toplandığı görülmektedir. Katılımcıların öğretmen denetimlerinin işlevsel olup olmadığı ile ilgili söyledikleri ifadelerden bazıları aşağıdadır:

...Çok yoğunuz. Öğretmen denetimlerine öncelik veremiyoruz. Bizim yaptı̆̆ımız öğretmen denetimlerinin okul kalitesine bir katkısı olmuyor... (M1).

...Ancak denetimler okul müdürünün öğretmenlerle arasının açılmasına yol açabiliyor. Biz burada ögrretmenlerle ikili ilişkilerimizi iyi tutmak zorundayız. Hele öğretmene not verirseniz bu daha büyük sıkıntılara yol açabiliyor. (M13)

Okul müdürleri olarak bizler daha çok kontrol amaçlı denetimler yapıyoruz. Denetimler yoluyla öğretmenlerin mesleki gelişiminin sağlayabildiğimizi düşünmüyorum. (M19)

Öğretmen denetimleri sonucunda verdiğimiz notlardan dolayı ciddi sıkıntılar yaşadık. Sendikaların ve öğretmenlerin ilçelere verdiği dilekçeler havada uçuştu. Bu insanların birbiriyle olan ilişkilerini de bozdu. (M20)

Okul müdürlerinin “ders denetimlerini nasıl yaptığınız hakkında bize bilgi verebilir misiniz?”, sorusuna verdikleri yanıtlar "ders denetimi” teması altında toplanmıştır. Ders denetimi temasına ilişkin alt temalar ve frekanslar Tablo 5'de sunulmaktadır. 
Tablo 5

Ders Denetimleri Temasına illişkin Alt Temalar ve Frekanslar

\begin{tabular}{|c|c|c|}
\hline Ana tema & Alt temalar & f \\
\hline \multirow{26}{*}{$\begin{array}{l}\text { Ders } \\
\text { Denetimi }\end{array}$} & Ders Öncesi & \\
\hline & Derslere çat kapı girerim & 16 \\
\hline & Hangi öğretmenin dersini denetleyeceğim tesadüfi gelişiyor & 14 \\
\hline & Hakkında şikayet olan öğretmenin ders denetimine öncelik veririm & 8 \\
\hline & Hangi dersi ne zaman denetleyeceğimi önceden planlarım & 6 \\
\hline & Dersine gireceğim öğretmene önceden bilgi veririm & 5 \\
\hline & Derse öğretmenle birlikte girerim & 4 \\
\hline & Ders Esnası & \\
\hline & Gözlem formu kullanırım & 20 \\
\hline & Gözlem yaparken bir yandan da not alırım & 16 \\
\hline & İdari işlerden dolayı derste 15-20 dakika durup ayrılırım & 16 \\
\hline & Ders esnasında sadece gözlem yapar derse müdahil olmam & 12 \\
\hline & Derse müdahil olur ve öğrencilere sorular sorarım & 7 \\
\hline & Notlarımı ders çıkışında yazarım & 4 \\
\hline & Dersin tamamında bulunmaya çalışırım & 4 \\
\hline & Ders Sonrasi & \\
\hline & Öğretmenle baş başa değerlendirme toplantısı yaparım & 12 \\
\hline & Öğretmenle değerlendirme toplantısı yapmam & 8 \\
\hline & Değerlendirme toplantısında iyi ve geliştirilmesi gereken yönleri dile getiririm & 7 \\
\hline & Değerlendirme toplantısında öğretmenle aram açılmaması için olumsuz yönleri dile getirmem & 5 \\
\hline & Ders D1ş1 Etkinlikler & \\
\hline & Ders dışı etkinlikleri gözlemlerim & 20 \\
\hline & Öğretmen hakkındaki kanaatim daha çok ders dışı gözlemlerimle oluşur & 16 \\
\hline & Ders dışı etkinlikleri daha çok önemserim & 14 \\
\hline & Ders dışı gözlemler yeterli bu nedenle ders denetimine girmeye gerek yok bence & 8 \\
\hline & $\begin{array}{l}\text { Ders içi ve ders dışı etkinlikleri birlikte değerlendirerek öğretmen hakkında kanaatimi } \\
\text { belirlerim }\end{array}$ & 4 \\
\hline
\end{tabular}

Tablo 5 incelendiğinde ders denetimi teması; ders öncesi, ders esnası, ders sonrası ve ders dışı etkinlikler şeklinde dört alt boyuta ayrıldığı görülmektedir. Ders öncesi teması; ““'derslere çat kapı girerim”, "hangi öğretmenin dersini denetleyeceğim tesadüfi gelişiyor”, "hakkında şikayet olan öğretmenin ders denetimine öncelik veririm", "hangi dersi ne zaman denetleyeceğimi önceden planlarım", "dersine gireceğim öğretmene önceden bilgi veririm” ve "derse öğretmenle birlikte girerim" şeklinde altı kategoriden oluşmaktadır. Katılımcıların ders öncesi teması ile ilgili söyledikleri ifadelerden bazıları aşağıdadır:

Genelde çat kapı giriyorum... Denetimlere tesadüfi giriyorum. Bir denetim planım yok. İs yoğunluğundan vakit kalırsa denetim için derslere giriyorum. Ama bir sinıftan şikayet geliyorsa (öğrenci, veli veya öğretmenin kendinden) o sinıfa öncelik veriyorum. Duruma göre o sinıfa birkaç kez giriyorum. Sınıfı ve sorunu anlamak için.(M3) 
Denetimleri belli bir plan dahilinde yapıyorum. Hangi günler hangi öğretmenlerin dersine gireceğimi önceden planlyorum. Hakkında şikayet olan öğretmenlerin ders denetimlerine öncelik veriyorum (M9)

Önceden öğretmene dersine gireceğime dair bilgi veririm. Zaten bir değerlendirme formu var ve bu form öğretmende de bulunuyor. (M13)

Daha önceleri random usulü öğretmenleri belirler ve dersine gireceğimi önceden söylerdim. Ama şimdi söylemiyorum. Çünkü o zaman ben dersine gireceğim için hazırlk yapıp geliyor. Haber vermeyince ögretmen müdür her an dersimi denetlemeye gelir düşüncesiyle daha hazırlkkl ve planlı ders işliyor. (M15)

Ders esnası teması; "gözlem formu kullanırım", "gözlem yaparken bir yandan da not alırım", "idari işlerden dolayı derste 15-20 dakika durup ayrilırım", "ders esnasında sadece gözlem yapar derse müdahil olmam", "derse müdahil olur ve öğrencilere sorular sorarım”, "notlarımı ders çıkışında yazarım" ve "dersin tamamında bulunmaya çalışırım” şeklinde yedi kategoriden oluşmaktadır. Ders esnası teması ile ilgili katılımcıların söyledikleri ifadelerden bazıları aşağıda yer almaktadır:

Derse ögretmenle birlikte giriyorum. Arkada 40 dakika oturuyorum. İdari işlerle ilgili bir telefon gelirse dersten çıkmak zorunda kaldığım oluyor. Dersi gözlemlerken not alıorum. Ama daha çok evrakları inceliyorum. (M1)

...Derslerde tam bir ders saati durduğum söylenemez. Ne zaman derse girsem ardindan hemen beni çağırıyorlar. Ya bir telefon geliyor ya da beni ilgilendiren başka bir durum. Artık biz okul müdürleri eğitimciden çok bir işletmeci olmuşuz. Derslerde daha çok sınıf yönetimi, öğrencilerle iletişsimi bunlara bakabiliyoruz. Ama dersinde ve branşında yeterli olup olmadığına bakamıyoruz. (M5)

Derste arka tarafta oturum dersi dinliyor ve gözlem yapıyorum. İdari, işlerin yoğunluğundan dersin tamaminda duramiyorum. Denetim en önemli idari iştir aslında. Ama yeterince önem vermiyoruz. (M12)

Derse öğretmenle birlikte girerim. Sinıfta uygun bir yere otururum. Derse müdahale etmem. Gözlem yaparım. Dersi gözlemlerken not alırım. (M14)

Ders sonrası teması; "öğretmenle baş başa değerlendirme toplantısı yaparım”, "öğretmenle değerlendirme toplantısı yapmam", "değerlendirme toplantısında iyi ve geliştirilmesi gereken yönleri dile getiririm" ve "değerlendirme toplantısında öğretmenle aram açılmaması için olumsuz yönleri dile getirmem” şeklinde dört kategoriye ayrılmaktadır. Ders sonrası teması ilişkin katılımcıların söyledikleri ifadelerden bazıları şunlardır:

İlk başlarda denetim sonrası değerlendirme yapıyordum. Ama sonraları gitmediğini fark ettim ve bıraktım. Denetim sonrası değerlendirmelerde daha çok olumlu yönleri söylemeyi ve öğretmenin olumlu yönlerini pekiştirmeyi tercih ettim. Olumsuzlukları geliştirilmesi gereken alanları öğretmenle konuşmaktan artık kaçıyorum. Çünkü yatay/informal ilişkilerimizi zedeliyor. (M6) 
Öncelikle olumlu özellikleri dile getiririm. Öğretmene, "gördüğüm olumsuzlukları da söylememi ister misin” derim. Eğer isterse ondan sonra olumsuz düşüncelerimi de paylaşırım.(M7)

Ders sonrası değerlendirme yapmıyorum. Bunu yapmamız lazım. Bu yönü eksik kalıyor. (M11)

Ders sonrası değerlendirme yaparım. Değerlendirme yaparken "şunu yapsak olabilir miydi" şeklinde önerilerde bulunuyorum. Bu sene öğretmenleri denetleyemedim. Derslere açık aramak için değil daha iyi nasıl olabilir için giriyorum. (M15)

Ders dışı etkinlikler teması; "ders dışı etkinlikleri gözlemlerim”, “öğretmen hakkındaki kanaatim daha çok ders dişı gözlemlerimle oluşur", "ders dişı etkinlikleri daha çok önemserim", "ders dışı gözlemler yeterli bu nedenle ders denetimine girmeye gerek yok bence" ve "ders içi ve ders dişı etkinlikleri birlikte değerlendirerek öğretmen hakkında kanaatimi belirlerim” şeklinde beş kategoriye ayrılmaktadır. Ders sonrası teması ilişkin katılımcıların söyledikleri ifadelerden bazıları şunlardır:

Sadece öğretmenlerin derslerine girilerek denetim yapılacă̆ına inanmıyorum. Biz zaten sınıfa girmesek de öğretmeni gözlemleyebiliyoruz.... Derse girmeden zaten öğretmen hakkında kanaatiniz oluşmuş oluyor. Bu nedenle de bence ders denetimine gerek yok. (M4)

Öğretmen hakkındaki kanaatim sadece ders denetimi üzerinden oluşmaz. Nöbet, derse giriş çıkış, rehberlik, velilerle olan iletişimi, eğitim etiği açısından öğretmenin davranışları, tutarlılık vb. yönler öğretmen hakkındaki bütüncül kanaatimin oluşmasını sağlar. Bu gözlemlerimden ya da bana gelen başka bilgilerden öğretmen hakkındaki bütüncül kanaatim oluşur. Öğretmenin okuldaki her türlü davranışını ve ilişkilerini gözlemlerim. Teneffüslerde öğretmen öğrenci ilişkilerini gözlemlerim...(M7)

Ders dişı etkinlikleri tam olan bir öğretmenin ders işleme boyutu da tama yakındır. Ders dışı etkinlikler öğretmenin kalitesinin bir göstergesidir diye düşünüyorum. (M20)

Katılımcılara "öğretmen denetimlerinin sadece müdürler tarafından yapılması ve müfettişlerin öğretmen denetimlerine girmemesi hususunda neler söylemek istersiniz?”, sorusu yöneltilmiştir. Bu soruya verilen cevaplar “müfettişlerin öğretmen denetimlerinde yer almaması" teması altında toplanmıştır. Müfettişlerin öğretmen denetimlerinde yer almaması temasına ilişkin alt temalar ve frekanslar Tablo 6'da sunulmaktadır. 
Tablo 6

Müfettişlerin Öğretmen Denetimlerinde Yer Almaması Temasına Illişkin Alt Temalar ve Frekanslar

\begin{tabular}{lll}
\hline Ana tema & Alt temalar & f \\
\hline & Müdür denetim uygulamaları birbirinden farklı iken müfettiş denetimlerinde ortak bir & 17 \\
& standart var & 17 \\
& Öğretmenler müfettişlerce yapılan denetimleri daha çok önemsiyor & 16 \\
& Müfettişlerin öğretmen denetimlerinden çektirilmesi denetim boşluğunun oluşmasına & 16 \\
Müfettişlerin & yol açtı & 14 \\
Öğretmen & Müfettişlerin teknik yönü daha güçlü & 14 \\
Denetimlerinde & Müfettişler denetimde uzmanlaşmışlar & 13 \\
Yer Almaması & Müfettişler öğretmen denetimlerine girmeli & 8 \\
& Müfettişler iletişşmde kırıcı dil kullanabiliyorlar & 8 \\
& Müfettişler öğretmeni tam olarak tanımazlar iken müdür daha iyi tanımaktadır & 4 \\
& Müfettşlerden alınıp tamamen müdürlere verilmesi daha iyi oldu & 3 \\
\hline & Hem müfettişlerce hem de müdürlerce yapılan denetimler yetersiz &
\end{tabular}

Tablo 6 incelendiğinde müfettişlerin öğretmen denetimlerinde yer almaması temasının; "müdürlerin denetim uygulamaları birbirinden farklı iken müfettiş denetimlerinde ortak bir standart var”, “öğretmenler müfettişlerce yapılan denetimleri daha çok önemsiyor”, "müfettişlerin öğretmen denetimlerinden çektirilmesi denetim boşluğuna yol açtı”, müfettişlerin teknik yönü daha güçlü", "müfettişler denetimde uzmanlaşmışlar", "müfettişler öğretmen denetimlerine girmeli”, "müfettişler iletişimde kırıcı dil kullanabiliyorlar”, "müfettişler öğretmeni tam olarak tanımazlar iken müdür daha iyi tanımaktadır", "müfettişlerden alınıp tamamen müdürlere verilmesi daha iyi oldu" ve "hem müfettişlerce hem de müdürlerce yapılan denetimler anlamsız" şeklinde on kategoride toplandığı görülmektedir. Katılımcıların müfettişlerin öğretmen denetimlerinde yer almaması teması ile ilgili söyledikleri ifadelerden bazıları aşağıdadır:

Müfettiş denetimleri öğretmenlerin derlenip toparlanmasını sağlıyordu...Biz her gün öğretmenlerle birlikteyiz ve içli dışlıyız. Bu nedenle okul müdürünün denetim misyonunu doldurması çok zor. 96 puan verdiğim bir öğretmen neden 96 puan diye odamı bastı. Verdiği not nedeniyle mahkemeye verilen müdür arkadaşlar var. Müfettişin öğretmen üzerinde sağladığı ă̆ırlı̆̆ın müdür tarafindan öğretmene hissettirilmesi mümkün değil. (M4)

Bana göre ne müdür denetimlerinin ne de müfettiş denetimlerinin bir katkısı yok. Her ikisi de okulu ve öğretmeni geliştirmiyor. Bu yüzden devletten bağımsız ya da özerk bir denetim sistemi kurulmasının daha faydalı olacağını düşünüyorum.(M6)

Okul müdürleri ile müfettişlerin ikisinin birlikte denetimlere girmesinin daha faydalı olacağını düşünüyorum. Dışarıdan bir göz olmalı. Okul müdürü de sınıf ortamında öğretmeni gözlemesi gerektiğini düşünüyorum. (M17)

Denetimlerin müdüre verilmesi daha iyi oldu. Müfettişin öğretmeni tam olarak tanıması mümkün değil. Ama ben tanıyorum. Öğretmen ne yapıyor ne yapmıyor çok iyi biliyorum (M18) 


\section{Sonuç, Tartışma ve Öneriler}

Araştırma bulgularına göre, araştırmaya katılan okul müdürlerinin tamamına yakınının öğretmen denetimlerinin nasıl yapılacağı ile ilgili bir hizmetiçi eğitim almadıkları ayrıca, öğretmen denetimine ilişkin verilen hizmetiçi eğitimlerin içeriğinin de yetersiz olduğu sonucuna ulaşılmıştır. Araştırmaya katılan okul müdürlerinin tamamı öğretmen denetimi konusunda iyi planlanmış, uygulamalı bir hizmetiçi eğitime ihtiyaçlarının olduğunu belirtmişlerdir. Okul müdürlerinin, öğretimsel liderlik, mesleki rehberlik, insani ilişkiler, iletişim, öğretmenin moral ve motivasyonunu yükseltme, objektif değerlendirme yapabilme, sınıf yönetimi, öğretim yöntem ve teknikleri gibi konularda yetkinliklerini artırmaya ihtiyaçlarının olduğunu söylemektedirler. Bu sonuçlara bakıldığında, araştırmaya katılan okul müdürlerinin öğretmen denetimi konusunda yetkinlik düzeylerinin düşük olduğu söylenebilir. Altun, Şanlı ve Tan (2015) ile Tonbul ve Baysülen’in (2017) yapmış oldukları araştırmada da müdürlerin öğretmen denetimi konusunda bir eğitimden geçmedikleri ve bu konuda hizmetiçi eğitime ihtiyaçlarının olduğu tespit edilmiştir. Bursalığlu (2015) öğretmen değerlendirmesini yapacak olan değerlendiricilerin bu alanda yetişmiş olmaları gerektiğini belirtmektedir.

Araştırma verilerine göre okul müdürlerinin yapmış olduğu öğretmen denetimlerinin yeterince işlevsel olmadığı sonucuna ulaşılmıştır. Bunun nedenleri olarak; idari işlerin yoğunluğundan dolayı denetime yeterince vakit ayıramama, öğretmen denetimi açısından okul müdürlerinin yetkinlik düzeylerinin düşük olması, müdür denetimlerinin öğretmenler tarafından yeterince ciddiye alınmaması, müdürün belirttiği eksikliklerin öğretmenler tarafından giderilmemesi, mesleki yetersizliği tespit edilen öğretmenlere yönelik bir yaptırım uygulanamaması, değerlendirme notu verilirken üst yönetimlerden ve sendikalardan baskı görülmesi, öğretmenin mesleki gelişimine yeterince katkı sunamama, müdür kaynaklı iletişim hataları, müdürün denetim rolünü yeterince oynayamaması, duygusal hareket ederek profesyonellikten uzaklaşması ve müdürlerin denetimler nedeniyle öğretmenler ile aralarının açılması istememeleri sayılabilir. Bu araştırmanın sonucuna benzer bir şekilde alanyazındaki bir çok araştırmada da, okul müdürlerinin öğretmen denetimlerine gereken zamanı ayırmadıkları tespit edilmiştir (Dibia, 2013; Ergen ve Eşiyok, 2017; Ikechi, 2010; Kaya ve Ülker, 2011; Onuma, 2015; Özbaş, 2002; Ünal ve Şentürk, 2011). Dibia (2013), Ergen ve Eşiyok (2017), Ikechi (2010) ve Onuma (2015) okul müdürlerinin öğretmen denetimlerine yeterince zaman ayırmamalarının idari işlerin yoğunluğundan kaynaklandığını belirtmişlerdir. Tonbul ve Baysülen'in (2017) öğretmen ders denetimlerinin sadece müdürler tarafından yapılmasına yönelik yapılan düzenlemenin müdürlerin yeterlikleri ve nitelikleri dikkate alındığında eğitim öğretimin niteliğine katkısı hususunda, başta müfettişler ve öğretmenler olmak üzere, müdürlerin dahi kaygı taşıdıklarını belirtmektedir. Onuma (2015) yapmış olduğu araştırmada okul müdürlerinin öğretmen denetimi konusunda beceri sahibi olmadıkları tespit edilmiştir. Ergen ve Eşiyok’un (2017) yapmış olduğu çalışmada, sınıf öğretmenleri, okul müdürlerinin sınıf denetimi yapmaları hususunda kararsız olduklarını belirtmişlerdir. Alanda yapılan çalışmaların sonuçları incelendiğinde bu araştırmanın sonuçları ile paralellik gösterdiği görülmektedir. 
Öğretmen ders denetimlerini okul müdürlerinin çoğunluğunun bir planlama dahilinde yapmadıkları, hangi öğretmenin ne zaman ders denetimi yapılacağının tesadüfü gelişebildiği ve duruma göre veli veya öğrencinin şikayetçi olduğu öğretmenin ders denetimine öncelik verildiği tespit edilmiştir. Okul müdürlerinin tamamının ders esnasında gözlem formu kullandıkları, büyük çoğunluğunun gözlemlerine ilişkin notları ders esnasında aldıkları ve derste 15-20 dakika durduktan sonra sınıftan ayrıldıkları sonucuna ulaşılmıştır. Ders denetiminin sonunda, bazı okul müdürleri öğretmenle birlikte değerlendirme toplantısı yaparken bazılarının yapmamayı tercih ettikleri görülmektedir. Ders denetimi sonrası yapılan değerlendirme toplantılarında, bazı okul müdürlerinin gelişime açık alanları vurgulamaktan genelde kaçındıkları, bunun nedeninin ise, okul müdürünün öğretmenle arasında soğukluğun oluşmasına yol açabileceği endişesinden kaynaklandığı tespit edilmiştir. Okul müdürlerinden bazılarının öğretmenleri sadece ders dışı etkinlikler üzerinden değerlendirdikleri görülmüştür. Bunun nedeninin bu tür okul müdürlerinin, öğretmenlerin ders dişı etkinlikleri iyi ise ders içi etkinliklerinin de iyi olacağı düşüncesine sahip olmalarından kaynaklandığı ileri sürülebilir. Oysa öğretmenin değerlendirilmesi en az yanılgı payı ile yapılmalıdır (Başar, 2000). Öğretmen hakkında karar verirken çok sayıda değişkenin gözetilmesi gerekir (Duverger, 1973). Alan yazında yapılan çeşitli araştırmalar da okul müdürlerinin ders denetimleri konusunda yetkinliklerinin düşük olduğunu ortaya koymaktadır (Altun, Şanlı ve Tan, 2015; Kılıç, 2013; Tonbul ve Baysülen, 2017; Uyar, 2015).

Araştırma bulgularına göre, müdürlerin denetim uygulamaları birbirinden farklı iken müfettiş denetimlerinde ortak bir standart anlayışının olduğu, öğretmenlerin müfettiş denetimlerini müdür denetimlerine göre daha çok önemsenip ciddiye aldıkları ve öğretmen denetimlerinin müfettişlerden alınıp tamamen okul müdürlerine verilmesinin beraberinde bir denetim boşluğunun oluşmasına yol açtığı sonucuna ulaşılmıştır. Ayrıca bazı okul müdürleri öğretmen denetimlerinin tamamen müdürler tarafından yapılmasının daha iyi olduğunu, müfettişlerin öğretmenlere kırıcı davranabildiklerini ifade etmektedirler. Diğer taraftan bazı okul müdürleri çeşitli uzmanlardan oluşan kurulların öğretmen denetimlerini yapması gerektiğini belirtmektedirler. Sailesh, Marohaini \& Sathiamoorthy (2011) öğretmen denetimleri ile ilgili yaptıkları araştırmada öğretmen denetimlerinin içerisinde öğretmenlerinde yer aldığ bir grup insan tarafından yapılması, denetimde sürekliliğin sağlanması ve müdürlerin öğretmen denetimlerini yaparken konunun uzmanlarından destek alması gerektiği belirtilmektedir. Altun (2014), Başol ve Kaya (2009) ile Yeşil ve Kış (2015) tarafından yapılan araştırmalarda öğretmenler ders denetimlerinin okul müdürü tarafından yapılmasını istedikleri belirtilmektedir. Tonbul ve Baysülen’in (2017) yapmış oldukları araştırmada ise, öğretmenler ve müdürler, müfettişlerin öğretmenlere mesleki rehberlik yapmaya devam etmelerini ancak, okul müdürlerinin de ders denetimi konusunda hizmet içi eğitimler alarak objektif bir şekilde öğretmen denetimlerini yapmaya devam etmelerini istedikleri tespit edilmiştir. Bu araştırmada da, okul müdürleri tarafından yapılan öğretmen denetimlerinin yeterince işlevsel olmadığı, müdürler dışında müfettişlerin veya farklı uzmanların da öğretmen denetimlerinde yer alması gerektiği sonucuna ulaşılmıştır.

Araştırma bulgularına dayalı olarak şu önerilerde bulunulabilir: 
1. Müdürlerin öğretmen denetimlerini daha işlevsel yapabilmeleri ve denetim konusundaki yetkinliklerini artırılabilmeleri için uygulama ağırlıklı hizmetiçi eğitimler düzenlenebilir.

2. Eğitim fakültelerinde, öğretmen denetimi bir ders olarak konulup işlenmesi farkındalığın artmasını sağlayabilir. Ayrıca okul yöneticilerinin ve yönetici adaylarının eğitim yönetimi ve denetimi alanında yüksek lisans yapması teşvik edilebilirler.

3. Sadece okul müdürlerinin değil maarif müfettişlerinin de öğretmen denetimlerinde görevlendirilmesi yoluna gidilebilir.

4. Bu araştırma devlet okullarında çalışan okul müdürleri ile yapılmıştır. Özel okullarda çalışan okul müdürlerinin öğretmen denetimlerine ilişkin görüşlerinin neler olduğunu araştıran çalışmalar yapılabilir. 


\section{Kaynaklar}

Altun, B. (2014). Denetime eleştirel yaklaşım: Öğretmen denetimi nasıl olmalı. (Yayımlanmamış yüksek lisans tezi). Adnan Menderes Üniversitesi, Sosyal Bilimler Enstitüsü, Aydın.

Altun, M., Şanlı, Ö. ve Tan, Ç. (2015). Maarif müfettişlerin, okul müdürlerinin denetmenlik görevleri hakkındaki görüşlerinin incelenmesi. Turkish Studies International Periodical For The Languages, Literature and History of Turkish or Turkic, 10(3), 79-96.

Arastaman, G., Fidan, İ. Ö. ve Fidan, T. (2018). Nitel araştırmada geçerlik ve güvenirlik: kuramsal bir inceleme. YYÜ Eğitim Fakültesi Dergisi (YYU Journal of Education Faculty), 15(1), 37-75.

Ashworth, P.D. \& U. Lucas. (1998). What is the world of phenomenography? Scandinavian Journal of Educational Research, 42, 415-31.

Aydın, İ. (2014). Öğretimde denetim (5. Baskı). Ankara: Pegem Akademi Yayınları.

Başar, H. (2000). Eğitim denetçisi (5. Baskı). Ankara: Pegem Yayıncılık.

Başaran, İ.E. (2000). Eğitim yönetimi: Nitelikli okul. Ankara: Umut Yayım Dağıtım.

Başol, G. ve Kaya, I. (2009). İlköğretim okulu öğretmenlerinin performanslarının okul z yöneticileri tarafından değerlendirilmesi üzerine görüşleri. I. Uluslararası TürkiyezEğitim Araştırmaları Kongresi Bildiri Kitapçı̆̆ , Çanakkale.

Berg, B. L. (2001). Qualitative research methods for the social sciences (Fourth Edition). Needham Heights, MA: A Pearson Education Company.

Bursalıŏlu, Z. (1991). Eğitimde yenileşme ve demokratik liderlik. Ankara Üniversitesi Eğitim Bilimleri Fakültesi Dergisi, 24(2), 669-674.

Bursalığlu, Z. (2015). Okul yönetiminde yeni yapı ve davranış (19. Baskı). Ankara: Pegem Akademi Yayınları.

Cogan, M. L. (1973). Clinical Supervision. Boston: Houghton Mifflin.

Creswell, J. W. (2007). Qualitative inquiry and research design: Choosing among five approaches. Thousands Oaks, CA: SAGE Publications, Inc.

Denzin, N. K. \& Lincoln, Y. S. (2005). The Sage Handbook Of Qualitative Research ( ${ }^{\text {rd }}$ Ed.). Thousand Oaks, CA: Sage.

Dibia, N.G. (2013). Extrinsic motivation and its effect on teachers' job performance. Journal of Nigerian Academy of Education, 8(1), 25-41.

Duverger, M. (1973). Sosyal Bilimlere Giriş. Ünsal Oskay (Çev.). Ankara: Bilgi Yayınevi.

Ergen, H. ve Eşiyok, İ. (2017). Okul müdürlerinin ders denetimi yapmasına ilişkin öğretmen görüşleri. Çă̆daş Yönetim Bilimleri Dergisi, 3(1), 1-19.

Guba, E. G. (1981). Criteria for assessing the trustworthiness of naturalistic inquiries. Educational Technology Research and Development, 29(2), 75-91.

Ikechi, M. (2010). Supervision in Nigeria: problem and prospects. Journal of Educational Studies and Research, 3(1), 30-38.

Haefele, D.L. (1981). Work Redesign For Organization Development. Making Organization Humane And Productive. New York: A handbook for Practitioners.

Harris, B. M. (1998). Paradigms and parameters of supervision in education. In F. Gerald \& E. Pajak (Eds.), Handbook of research on school supervision. NY: Simon and Schuster Macmillan.

Henson, K. A. (2007). Supervision: A Collaborative Approach To Instructional Improvement. USA: Waveland Press, Inc.

Kaya, S. ve Ülker, Y. (2011). İlköğretim okulu müdürlerinin sını içi etkinliklerin denetiminde yapmakta olduğu işler konusunda öğretmen görüşleri. III. Uluslararası Katılımlı Eğitim Denetimi Kongresi, 22-24 Haziran 2011, Mersin Üniversitesi, Mersin. 
Kılıç, Y. (2013). İlköğretim okullarındaki yönetici ve öğretmenleri eğitsel denetim ve örgüt iklimine ilişkin algılarının değerlendirilmesi (Batman ili örneği). (Yayımlanmamış yüksek lisans tezi). Dicle Üniversitesi Eğitim Bilimleri Enstitüsü, Diyarbakır.

Knafl, K. A. \& Howard, M. J. (1984). Interpreting and reporting qualitative research. Research in Nursing \& Health, 7(1), 17-24.

Knoll, M. K. (1987). Supervision for better instruction. New Jersey: Prentice Hall, Inc.

Lunenburg, F. C. \& Ornstein, A. C. (2013). Eğitim Yönetimi. Gökhan Arastaman (Çev.). Ankara: Nobel Yayıncilik.

Marks, J. R., Stoops, E. \& King-Stoops, J. (1985). Handbook of instructional supervision: A guide for the practicioner. Boston: Allyn and Bacon

MEB, (2014). Millî Eğitim Bakanlığı Rehberlik ve Denetim Başkanlığı ile Maarif Müfettişleri Başkanlıkları Yönetmeliği, Resmi Gazete, Sayı: 29009. [Online]: http://www.resmigazete.gov.tr/ eskiler/2014/05/20140524-18.htm adresinden 17 Temmuz 2017 tarihinde indirilmiştir.

Marzano, R. J. (2012). The two purposes of teacher evaluation. Educational Leadership, 70(3), 14 - 19.

Marzano, R. J. \& Toth, M. (2013). Teacher evaluation that makes a difference: A new model for teacher growth and student achievement. Alexandria, VA: Association for Supervision and Curriculum Development.

Morse, J. M. (1991). Strategies for sampling. In: J. M. Morse (Ed.). Qualitative Nursing Research: A Contemporary Dialogue (pp. 127-145). London: Sage Publications.

Mohanty, J. (2005). Educational Administration, Supervision And School Management. USA: Deep \& Deep Publications.

Onuma, N. (2015). Principals' management support practices for enhancing teachers' performance in secondary schools in Nigeria. Journal of Emerging Trends in Educational Research and Policy Studies, 6(1), 11-17.

Özbaş, M. (2002). İlköğretim okulu müdürlerinin sınıf içi etkinliklerin denetiminde yapmaları zgereken ve yapmakta oldukları işler konusunda müdür ve öğretmen görüşleri. (Yayımlanmamış yüksek lisans tezi). Hacettepe Üniversitesi Sosyal Bilimler Enstitüsü, Ankara.

Özden, Y. G. (1992). Denetim olgusu. Denetim Dergisi, 2 (78).

Sailesh S., Marohaini Y. \& Sathiamoorthy K. (2011). Instructional supervision in three asian countries-what do teachers \& principals say? 2011 2nd International Conference on Education and Management Technology, IPEDR, (13), IACSIT Press, Singapore

Sergiovanni, T. J. \& Starratt, R. J. (1979). Supervision human perspectives.USA: McGraw-Hill, Inc.

Shenton, A. K. (2004). Strategies for ensuring trustworthiness in qualitative research Project, Education for Information, 22(2), 63-75

Shinkfield, A. J. \& Stufflebeam, D. L. (1995). Teacher evaluation: Guide to effective practice. Boston, MA: Kluwer Academic

Sullivan, S. \& Glanz, J. (2005). Supervision That Improves Teaching, Startegies And Techniques. Thousand Oaks, California: Corwin Press.

Sullivan, S. \& Glanz, J. (2009). Supervision That Improves Teaching And Learning: Strategies And Techniques. CA:Corwin A Sage Company.

Taymaz, H. (2015). Eğitim Sisteminde Teftiş: Kavramlar, İlkeler ve Yöntemler. (11. Baskı). Ankara: PegemA Yayınlar1.

Tonbul, Y. ve Baysülen, E. (2017). Ders denetimi ile ilgili yönetmelik değişikliğinin maarif müfettişlerinin, okul yöneticilerinin ve öğretmenlerin görüşleri açısından değerlendirilmesi. İlköğretim Online, 16(1), 299-311. 
Tufford, L. \& Newman, P. (2012). Bracketing in qualitative research. Qualitative Social Work, 11(1), 80-96.

Uyar, A. M. (2015). Eğitim denetmenlerinin var olan teftişsistemi ile ilgili algıları ve yeni bir teftişsisteminden beklentiler: bir durum çalışması. (Yayımlanmamış yüksek lisans tezi). Ortadoğu Teknik Üniversitesi, Sosyal Bilimler Enstitüsü, Ankara.

Ünal, A. ve Şentürk, R. (2011, 8-10 Eylül). İlköğretim okul müdürlerinin ders denetimi uygulamaları. 20. Ulusal Eğitim Bilimleri Kurultayı, Burdur.

Wiles, K. (1967). Supervision For Better Schools. USA: Prentice-Hall International, Inc.

Yeşil, D. ve Kış, A. (2015). Okul müdürlerinin ders denetimine ilişkin öğretmen görüşlerinin incelenmesi. İnönü Üniversitesi Eğitim Bilimleri Enstitüsü Dergisi, 2(3), 27-45.

Yıldırım, A. ve Şimşek, H. (2011). Sosyal Bilimlerde Nitel Araştırma Yöntemleri. Ankara: Seçkin Yayıncılık. 